\title{
THE EDITOR'S INTRODUCTION
}

Among all the great chivalric heroes once celebrated in early romance, three only are now enshrined in the British Dictionary of National Biography: Arthur of Camelot, victor over the Saxons; Richard I or "Cour-de-Lion," conqueror of the Saracens; and Guy of Warwick, a knight best known, if at all, in Drayton's accolade, "Hercules of England." Of King Arthur and his Round Table we are still reminded in varying accents of constant appealin the wondrous version Malory first drew out of old "Frensshe bookes," in the sonorous poems of Spenser and, later, of Tennyson and Swinburne, then again in Wagner's operatic Lobengrin, Parsifal, and Tristan und Isolde. Even the lowly ravens, as Don Quixote recalled, are ever-present memorials, since Arthur was turned into one. Great Britain will endure then, as guards at the Tower now inform us, only so long as the ravens live.

Against all these testimonies large and small to Arthur there is, admittedly, little contemporary evidence of King Richard, even less of Sir Guy. Yet, if judged by the number of surviving manuscripts, the tale now least often told was once most highly esteemed. For Arthur there exists a single medieval script (and that discovered as recently as 1934), for Richard as many as seven, for Guy no less than twenty-one. To this count may be added various allusions, and as many entries in the catalogues of noble libraries, all indicating that, before these romances were reduced to print, and to the vulgar tongue of later time, Guy was avidly perused in Anglo-Norman courtly circles. Our Crusader-hero was long remembered even in far-off
Jerusalem, where in 1410, according to Dugdale, a supposed descendant was received with great acclaim. Granted all these early manifestations, how may we explain the present diminution of Guy and, leaving Richard aside, the continual exaltation of Arthur?

Perhaps there are several explanations, all in Arthur's favor. Given a worthy subject the first requisite is that some early genius, after his own reading of the manuscripts, then abridge these unending tales, refine away their dross, and with pure metal fashion an enduring legend whole, complete and, whatever its length, all compact. For Artbur that genius was found in Sir Thomas Malory, a knight as it happens also from Warwickshire, but one quite unconcerned with the great exploits then related of a local celebrity. Malory was intent upon ancient times and places and, in the aura which such distance makes enchanting, was able to create from olden days that marvellous kingdom to which we all still owe allegiance. For $G u y$, on the other hand, if there was any such interpreter he was soon stifled, his version left unread, and the story itself thus allowed to degenerate in the clumsy hands of English versifiers, chapmen, and other drab purveyors. As a thing of shreds and patches Guy down to the nineteenth century continued to enjoy an extraordinary vogue, surpassing indeed all others, ${ }^{1}$ but one which posterity could never accept.

Another requirement or, rather, a very considerable advantage, is that the matter be of

${ }^{1}$ R. S. Crane, "The Vogue of Guy of Warwick from the Close of the Middle Ages to the Romantic Revival," $P M L A, \operatorname{xxx}$ (1915), 125-194. 
such complexity as to excite the widest range of emotions. A knight, after all, has only one way of winning the lady fair, or of advancing his own honor, and that by demonstrated prowess in battle. The demonstration can be varied, somewhat, by increasing the number of antagonists, or by substituting dragons and other monsters; but even then the ways of hacking down the foe are severely limited. Further variation is possible by introducing other ladies of more or less discretion, and in their service more knights, all of whom, if aided occasionally with the magic of a Merlin, can then perform even more spectacular feats, both romantic and bellicose. The celtic King, already far removed from the dull demands of reality, and already surrounded at his Round Table with 140 knights, thus was susceptible, in Malory's treatment, to the greatest complication, to a very Artburiad. "For herein may be seen," as Malory's first printer observed, "noble chyualrye, Curtosye, Humanyte, frendlyness, hardynesse, loue, frendshyp, Cowardyse, Murdre, hate, vertue, and synne. Doo after the good," he then exhorts his readers, "and leue the euyl, and it shal brynge you to good fame and renommee." Such felicitous advice was not well received by Roger Ascham, Queen Elizabeth's tutor, who was much offended by all the "synne"-beginning at once, we remember, in the unseemly way Uther Pendragon, with Merlin's assistance, begat Arthur upon Igraynebut this story was never intended for readers with delicate sensibilities.

With Guy Ascham and associates would have been better pleased, for here appears only a single hero, a stolid Saxon apparently, one sorely tempted almost beyond endurance yet, when so reminded by lesser magic, ever steadfast in his concept of love and honor. His exploits can be varied too, but, within the confinements of singularity, only in the limited manner just prescribed. Principally the method in Guy is to let the heroine, Felicia, demand ever more. At first she wishes her knight to seek only the usual fame and honor (Chapters 118); then, upon his return with this much achieved, she orders him to become the "best knight in the world" - a task requiring the most enormous accomplishments, all consummated, rightly enough, again on English soil, where he slays a dragon (19-46). With all that attained Guy then, after forty days of bliss (47-48), suffers the pangs of remorse for these his many misdeeds, these very acts which brought him honor, and wanders off a pilgrim with continued "prayers and orisons" to expiate his sins, proper expiation here culminating in the slaying of a Saracen (49-57). Returning once more, now just in time to decapitate the Danish giant Collebrand (58-60), he retires to Warwick, there unrecognized to a hermitage, where he dies in the arms of his beloved, now also much given to saintly deeds (61-63). Phase by phase all this is susceptible to complication but, in the absence of other lords and ladies, or in their removal to minor roles, only by accretion of detail.

How the Guy story may be enlarged, to good effect, will concern us later. How it stands now, in relation to Artbur, is a question not readily debated; for the two, though of the same genre, and emerging both out of Anglo-Norman legend, are quite disparate. Arthur with all his knights remains par excellence the "matter of Britain," comparable only to similar romantic cycles: of Charlemagne, Roland, Oliver, and others for the matter of France, and of the many Trojan heroes for the matter of Rome the Great. Guy, in a noncyclic or "linear" tradition, still is unchallenged among native English heroes of lesser renown. Among these we know something of Richard, though more from history than romance; but what now of Athelstan, Beves of Hampton, Fulk Fitz-Warine, Gamelyn, Havelock the Dane, King Horn, Horn Childe, or Raimbron the son of Guy? All these are nonentities to the present reader, all oft-told 
tales now unrecalled because they are unrelated to any larger complex. Yet various adventures of Gawain and the Green Knight, uncollected by Malory, are still remembered since Gawain was of Arthur's court, and thus of some greater association. Separate and apart, Guy cannot do alone, even as a "Hercules," all that the knights of the Round Table do together.

Still another and more exacting requisite is that these unstable tales soon evolve, in their most perfect form, to a fixed and inalterable state readily transmitted to later times. Now almost alone among all British romances both Artbur and Guy, each in its best rendition, quickly attained a permanent form in print, the Malory version in Caxton's issue of 31 July 1485 , the other account in Regnault's edition of 7 March 1525. Fortunately the Artbur was in English, now the established language of all Britain, and so in its most readable state went through six editions still extant in a hundred years, and countless others thereafter. Most unfortunately the Guy remained in French, a tongue then little different from Anglo-Norman, earlier lingua franca of the Crusaders, but now completely foreign both to the subject, a knight of Britain, and to those who would later read of this matter. Hence the Regnault edition was alienated and passed, still untranslated, to one other only: an undated issue which cannot be located. Till now our "Hercules of England" thus remains only as a stranger in another country, and one practically unnoticed in his native land.

In 1821 , however, someone did take notice -indeed another attendant maiden. This latterday heroine, named Caroline Clive, demanded nothing less than Guy's constant presence and, to secure that forever, completed a translation then huddled away, from daughter to daughter, through succeeding generations. Of these remarkable ladies more will be said after their work is presented. With their unique manuscript before us our responsibility here must be, first to the unknown French redactor, then to his text.

The original editor, writing in the fifteenth century, immediately betrays his nationality at the beginning of the text proper where, along with more familiar references, he garbles one into "Wringchim," a locale which cannot be identified among English place names. Then he refers to "Warlingford," so always in his French, so always in Caroline Clive's precise transcript, but never so in any English record. Then again in his prologue he writes as an envious foreigner, here looking from some distance upon Englishmen as "very much stronger and more powerful in their limbs than those of neighbouring lands." Much later, at the end of Chapter 46, he intimates that he has never been to Warwick, and must therefore rely upon "the report of some persons who have been there." In accounts of his own country, however, the editor is quite exact. Where in other versions Guy simply travels from Warwick to Rouen, in this he proceeds via "the harbour of Harfleur, which is upon the course of the River Seine"-and, we may add, the most direct approach to his destination. Once at Rouen the hero then sallies out to his first tournament, we know not where in the other tales, in Flanders according to this.

The prologue, entirely the prose editor's invention, further exhibits his determination to particularize all generalities. In the other, poetic accounts, all beginning somewhere in limbo as a tale which "should be told," we must read on, through the equivalent of nineteen chapters, to ascertain that the adventures here related take place in the reign of Athelstan. In this we are immediately apprised of that era and, in the same sentence, given an exact date, A.D. 424. Now if we are pedantically inclined it may be argued that the date is inconsistent with all the other allusions here introduced: Athelstan and the legendary Guy are of the tenth century; the Barons War of the thirteenth; Arthur, 
supposedly in an earlier age, of the fifth, the very time of this story. Such anachronisms must be discounted by readers of romance. All that really matters here is verisimilitude, an artistic truth in which the present editor excells every other.

Once again, in the text, we perceive the editor engaged, where necessary, in reducing vague prolixity to more certain fact or, at least, to more entertaining commentary. Among the references available to him, here designated as $a-d,{ }^{2}$ he must have been horrified at the representation of Felicia, the heroine, as a formidable polymath, competent in all things, including even the seven medieval arts. On this last accomplishment-a very unappealing feature to any modern reader - the other editors insensitively expatiate in ever-increasing measure:

(a) Curteise ert e enseigné,

De tuz arz ert enletré;

Ses meistres esteient venuz

De Tulette, tuz blancs chanuz,

Ki l'aperneient d'astronomie,

D'arismatike, de jeometrie;

Mult par ert fere de corage. (63-69)

(b) Wyse sche was and curtes of mowthe,

All the vii arse sche cowthe.

Sche had maysturs at hur honde,

The wysest men of that londe,

And taght hur astronomye,

Arsmetryck and gemetrye.

2 Of the four medieval verse texts now edited, the first is in French, the other three in English: (a) British Museum Add. MS. 38662, ed. Alfred Ewert, Gui de Warewic, Paris, 1932-1933, 2 vols.; (b) Cambridge Univ. MS, Ff 2.38, ed. Julius Zupitza, E.E.T.S. extra series 25-27, London, 1875-1877; (c, d) parallel texts, Auchinleck MS and Caius MS 107, ed. Julius Zupitza, E.E.T.S. extra series, 42, 49, 54, London, 1883-1891. Manuscript $b$, though designated by Zupitza as of a second version, later transcribed than $c$ or $d$, derives from a text which is of an earlier state approximating the French $a$. Text $a$ in turn descends from an unknown manuscript first composed, Professor Ewert suggests, at the Abbey of Osenay, Oxfordshire, ca. 1232-1242.
That mayde was of grete prys,

For sche was bothe warre and wyse. (63-70)

(d) She was therto curteys and free ywys, And in the .vii. artes well lerned, withoute mys.

All the .vii. artis she kouthe well, Noon better that euere man herde tell.

Hir maisters were thider come

Oute of Tholouse all and some;

White and hoore all they were,

Bisy they were that mayden to lere;

And they hir lerned of astronomye,

Of Ars-meotrik, and of geometrye.

Of Sophestrie she was also witty,

Of Rethoric, and of other clergye;

Lerned she was in musyke;

Of clergie was hir noon like.

She was a woman of grete corage,

Wise and faire and of gaye parage.(78-94)

To counter all this inane elaboration our editor simply reports that Felicia "was full of all pious manners and knowledge to be taught to all ladies." Of course, as he concedes, "many authors ... have exerted themselves" to much greater lengths; but "for the sake of brevity" he is content to observe, finally, that "she was very perfect in beauty, sense and gracious demeanour." So idealized, Felicia then becomes, not the proud princess of earlier legends, but a gentle damsel more charitably disposed to Guy.

For Guy himself our editor is equally solicitous. Other accounts ramble on, when he is first introduced, the earliest mentioning unnumbered maidens swooning in his presence (a), others assessing the female count at thirty $(b, c)$, another insisting that it was "moo than thirty" $(d)$. Throughout in these versions there is similar exaggeration, all designed to magnify Guy's importance and, at times, reaching preposterous dimensions. When Guy dies we are variously informed that St. Michael's white dove carried his soul to heaven $(b)$, that Michael himself carried it away $(d)$, that 
angels hovered about ( $a$ ), and (c) that the angels numbered exactly, 1,007! Then we are told that thirty knights $(b)$ or, better yet, that one hundred men $(a, c)$ were unable to lift his body. All this crude numerology the editor prunes away as intolerable stuff for later readers.

Apart from this judicious trimming we should single out, lastly, several instances of the editor's continual effort to enlarge, in more significant ways, the dignity of his characters, and thereby develop the role they play in the story. No wonder Felicia, in the other tales, had only contempt at first for Guy; his father was merely a "styward" to hers. Here she is more amenable, partly because she is now inclined that way, as already noted, partly because the father now is of some consequence: "a very sage and valiant knight, . . . Lord of Wallingford ${ }^{3}$ upon Thames," much "renowned for high prowess" and espoused to "a very beautiful and gracious lady of high lineage, daughter of the Earl of Lancaster." Guy's companion, Herolt Dardenne, is similarly ennobled as "a wise and valiant knight," and thus enabled to perform a tender service unmentioned in other accounts. Elsewhere a boorish Guy, with no one able to act for him, and without any credentials himself, at once insults the lady, who then, quite rightly, threatens to have his head cut off. Not very admirable this, and not very conducive to later adventures. Here, to the contrary, a bashful suitor asks his esteemed friend and "governor" to intercede;

3 "Warlingford" and other corruptions are silently amended in this edition if the correct spelling is known. and through Herolt's delicate mediation, and much fine language all around, everything is brought to a gentle compact: Felicia's "gracious kiss" as an "assurance of love." And so on Trinity Sunday young Guy is exalted to knighthood, the necessary condition for demonstrating noble prowess.

To authenticate these many embellishments the editor, like his contemporary Malory, frequently alludes to various sources real or imagined, only one of which is specifically identified: "the true history and right chronicles of [Guy] which are in the Abbey of Glastonbury." Thus again the redactor, this second Malory, gracefully evokes, without mentioning a name, the spirit of Arthur; for in these hallowed precincts, we recall, lies the grave of that magnificent king and of his queen, Guinevere. Whether Glastonbury ever possessed any such history is quite immaterial and beyond discovery; the first great abbey was destroyed by fire in 1184 , long before our editor was born and, a century after his writing, in 1539, the second one finally was dissolved by Henry VIII. Other than the rudimentary poetic versions, no "true history" of Guy is known to exist, and none is needed to verify the greater truth of ancient romance, here so well conveyed.

The edition now presented, though essentially the work of Caroline Clive, has been modernized according to principles set forth in the epilogue. What the translator has prepared, at a time very near our own, is best made completely ours, so that, without any further hindrance, Guy of Warwick may at last come immediately before the reader.

William B. TodD 